\title{
Estimation of soil erosion in some sections of Lower Jinsha River based on RUSLE
}

\author{
Liguang Jiang $\cdot$ Zhijun Yao $\cdot$ Zhaofei Liu $\cdot$ Shanshan Wu \\ Rui Wang $\cdot$ Lei Wang
}

Received: 28 August 2014/ Accepted: 19 December 2014/Published online: 9 January 2015

(C) Springer Science+Business Media Dordrecht 2015

\begin{abstract}
Soil erosion increasingly poses a great threat to human food security and environmental quality. It is necessary to implement the assessment of soil erosion so as to provide precautionary measures and relevant suggestions for soil conservation. In this paper, the soil erosion model, revised universal soil loss equation (RUSLE), was used to quantify the soil loss in a large mountainous area of Lower Jinsha River Basin. The analysis of the datasets by means of geographic information systems (GIS) together with RUSLE led to the estimation of soil erosion. Results show that the average annual soil erosion was estimated at $52.1 \mathrm{t} \mathrm{ha}^{-1}$ year $^{-1}$ and the total annual soil loss was $4.5 \times 10^{8}$ t. The highest erosion was found along the main course of Jinsha River. Soil erosion was serious in the elevation zone between 1,675 and 2,153 $\mathrm{m}$ and slope zone with slopes between $15^{\circ}$ and $35^{\circ}$. As for land use types, cropland and grassland contributed $84.1 \%$ to total soil loss due to the large areas and higher erosion rates. The results can be used to advice the local government in prioritizing the areas of immediate conservation practices.
\end{abstract}

Keywords Soil erosion - Soil loss $\cdot$ RUSLE $\cdot$ Mountain region $\cdot$ Jinsha River

\section{Introduction}

Soil erosion has long been recognized as a very serious worldwide environmental problem (Saadat et al. 2014), especially in developing countries where economic development is

L. Jiang $\cdot$ Z. Yao $(\bowtie) \cdot$ Z. Liu $\cdot$ S. Wu $\cdot$ R. Wang $\cdot$ L. Wang

Institute of Geographic Sciences and Natural Resources Research, Chinese Academy of Sciences,

Beijing 100101, China

e-mail: yaozj@igsnrr.ac.cn

R. Wang $\cdot$ L. Wang

University of Chinese Academy of Sciences, Beijing 100049, China 
pursued, while the protection of environment is disregarded. Soil erosion is a natural process of detachment of soil particles and has an irreversible effect on the environment. Soil particles detached from the soil surface carry nutrients, pesticides, and other harmful farm chemicals into rivers, streams, and groundwater resources (Pan and Wen 2014; Yang 2014), which not only causes damage to soil and agricultural production, but also affects water quality and hydrological systems (Lee 2004; Lu et al. 2004). What is more, erosion is increasingly being recognized as a hazard. Within an environmentally acceptable sustainable agricultural policy, the reduction in soil erosion must be a priority (Lee 2004).

Soil conservation planning often requires estimation of soil erosion at a catchment or regional scale. If the magnitude and features of spatial structure of soil erosion are clear, the conservation practices to alleviate the problem can be effectively carried out (Onyando et al. 2005). Predictive models are useful tools to generate the quantitative estimates necessary for designing sound conservation measures (De Asis and Omasa 2007). There are several models to estimate the soil loss, such as EUROSEM, WEPP, SHE, WaTEM/ SEDEM, SEMMED and so on (Merritt et al. 2003). However, the most widely used model is an empirical model, the (revised) universal soil loss equation (RUSLE/USLE). The USLE and RUSLE have been applied at national level (Briggs et al. 1992; Van der Knijff et al. 2000), regional level (Ma et al. 2003; Xu et al. 2013) and basin level (Naqvi et al. 2013; Ozsoy et al. 2012) in different environments worldwide.

Soil erosion is a severe issue that poses great threats to the ecological environment and human living in the lower reaches of the Jinsha River, the upper reach of the Yangtze River. This area is dominated by mountain and plateau landforms, in which the ecosystem
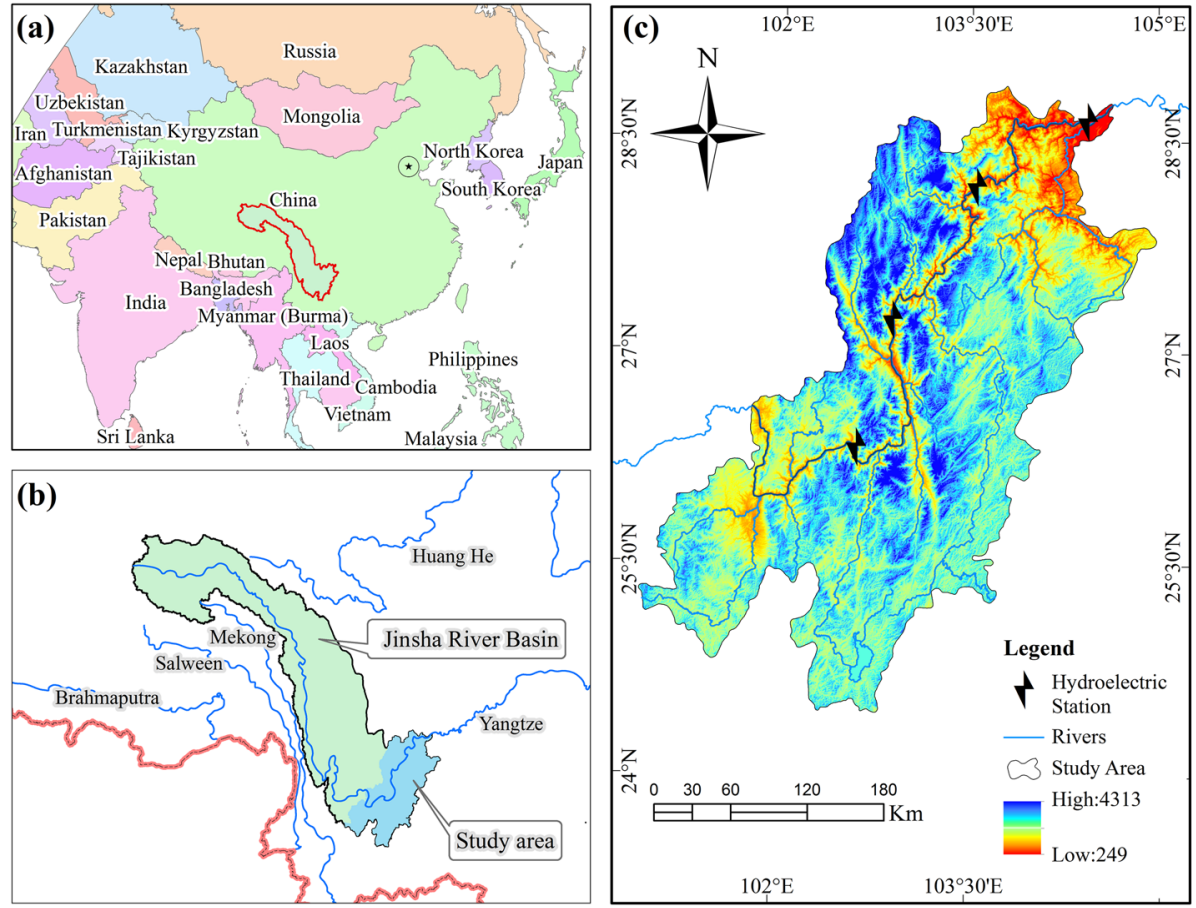

Fig. 1 Location, boundary, and watershed of the Lower Jinsha River 
is very fragile and susceptible to soil erosion due to deforestation, land reclamation, and other inappropriate land use (Long et al. 2006). In the 1970s and 1980s, there has been a rapid growth in population in the upper Yangtze River watershed. Thus, a large area of grassland and forest has been reclaimed to feed the population, thereby resulting in severe soil erosion and ecosystem damage (Ma et al. 2003). The soil loss in this region is a crucial issue for the government and has raised great public concern.

Estimation of soil erosion at a regional level poses a big challenge due to the different geographic features and the costly and time-consuming practical field methods which requires a lot of resources. However, the application of RUSLE is feasible and can be achieved because of the readily available data and its simplicity to apply with GIS and RS. The objective of this research is to quantify the magnitude and spatial distribution of soil erosion within the study area, in addition to yield an overall estimate of soil loss. The study results will provide useful information for soil conservation.

\section{Study area}

The study area is located in the lower reaches of Jinsha River basin which is the upper reach of Yangtze River, lying in the southwest part of China (Fig. 1). It lies between $100^{\circ} 50^{\prime}-105^{\circ} \mathrm{E}$ and $24^{\circ} 25^{\prime}-29^{\circ} \mathrm{N}$ stretching from southwest to northeast with an average elevation of 2,016 $\mathrm{m}$ a.s.l. The administrative region contains three provinces of Yunnan, Guizhou, and Sichuan under which there are 67 counties, covering a total area of approximately 8.7 million ha.

It represents diverse landscape types, including alpine valley, karst valley, lake, hill, etc. There are a variety of vegetation types in this area, which are dominated by alpine shrub, alpine meadow, farmland, and forest. This region belongs to the humid subtropics of south Asia, and the climate is mainly characterized by the southwest and southeast monsoons in wet season in addition to prevailing wind from the west in cold season (Fan et al. 2004; Shen et al. 2013; Zhuang and Ge 2012). Mean annual precipitation is $893 \mathrm{~mm}$, and the rainy season occurs between May and October, accounting for $88.1 \%$ of annual precipitation. Mean annual temperature is $15^{\circ} \mathrm{C}$. June, July, and August are the warmest months with temperatures over $20^{\circ} \mathrm{C}$. However, the precipitation and temperature are inhomogeneous due to the mountainous terrains.

\section{Materials and methods}

\subsection{Materials}

To achieve the objective, the following datasets are collected: (1) Monthly precipitation of 23 rain-gauge stations from 1955 to 2013, downloaded from China Meteorological Data Sharing Service System (http://cdc.cma.gov.cn/home.do). (2) Soil map at 1:1,000,000 scale of The Second Soil Survey Data of China, including subsoil sand fraction, silt fraction, clay fraction, and topsoil organic carbon, provided by Cold and Arid Regions Science Data Center at Lanzhou (http://westdc.westgis.ac.cn/). (3) An ASTER GDEM with a spatial resolution of $30 \mathrm{~m}$ of the area is obtained from Geospatial Data Cloud (http:// www.gscloud.cn/). (4) SPOT VGT datasets with 1-km spatial resolution from April 1998 to July 2008 and August 2008 to December 2012 are acquired from the Cold and Arid Regions Science Data Center at Lanzhou (http://westdc.westgis.ac.cn) and the Vlaamse 
Instelling Voor Technologish Onderzoek (http://www.vgt.vito.be/), respectively. (5) Land cover dataset with 1-km spatial resolution is from Cold and Arid Regions Science Data Center at Lanzhou (http://westdc.westgis.ac.cn).

\subsection{Model description}

The soil erosion model used in this study is the RUSLE model taking the following form (Renard et al. 1997):

$$
A=R \times K \times \mathrm{LS} \times C \times P
$$

where $A$ is the estimated average annual soil loss $\left(\mathrm{t} \mathrm{ha}^{-1}\right.$ year $\left.^{-1}\right) ; R$ is the rainfall-runoff erosivity factor $\left(\mathrm{MJ} \mathrm{mm} \mathrm{ha}{ }^{-1} \mathrm{~h}^{-1}\right.$ year $\left.^{-1}\right) ; K$ is the soil erodibility factor (t ha h ha ${ }^{-1} \mathrm{MJ}^{-1} \mathrm{~mm}^{-1}$ ); $L S$ is the topographic factor, derived from a combination of the slope steepness factor and slope length factor (dimensionless); $C$ is the cover and management factor (dimensionless); $P$ is the conservation support practice factor (dimensionless).

The RUSLE is a well-established empirical model and widely applied by many researchers. The combined use of RUSLE, GIS, and RS techniques makes it economical and feasible to estimate the soil erosion and its spatial distribution even for larger areas (Chatterjee et al. 2014). Under the ArcGIS 10.1 environment, all the factors of Eq. 1 are described as raster layers and a result layer of soil loss $(A)$ is figured out through raster calculation function. All layers are unified to a $1 \mathrm{~km}^{2}$-cell basis resolution and so some layers are processed by upscaling techniques. The computations of the parameters are described in following sections, respectively.

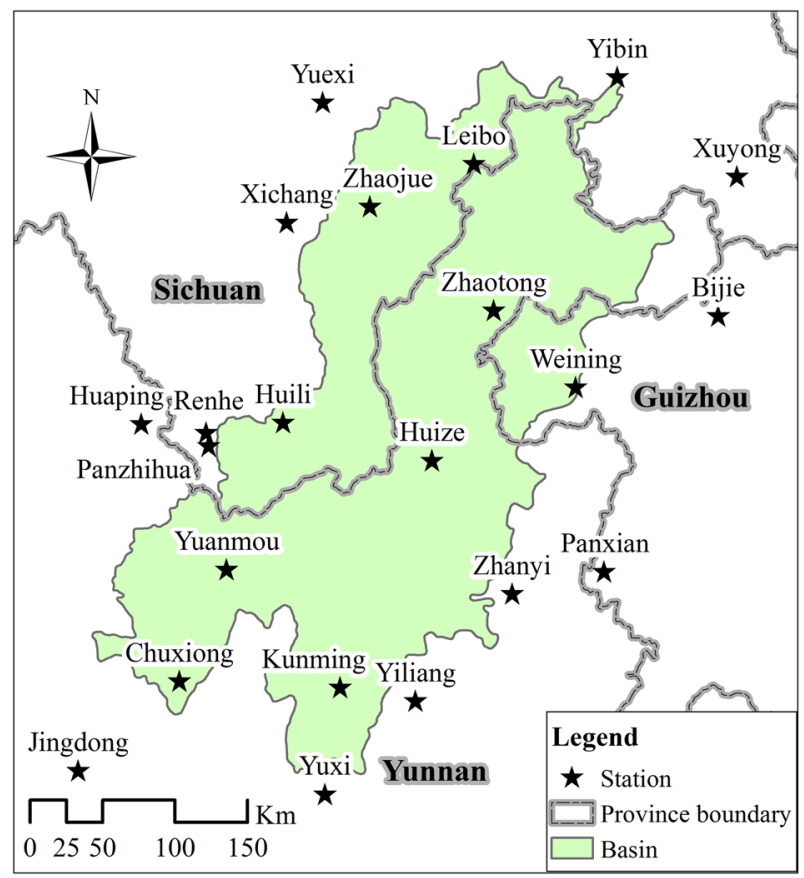

Fig. 2 Location of rain-gauge stations used in this study 
3.3 Spatial data process and parameter determination

\subsubsection{Rainfall erosivity factor $(R)$}

$R$ factor is the long-term annual average of the product of events of rainfall kinetic energy, quantifying the effect of rainfall and associated runoff impact (Chatterjee et al. 2014; Onori et al. 2006). The original method to calculate the rainfall erosivity factor $(R)$ requires pluviographical records and these data, however, are not always available. Furthermore, its preciseness depends on the temporal length and resolution of precipitation series (da Silva 2004; Onori et al. 2006). Given the restrictions, numerous alternative approaches have been developed to calculate $R$ [e.g., (da Silva 2004; Diodato 1999; Kavian et al. 2011; Shamshad et al. 2008; Yu and Rosewell 1996a, b)]. In this study, we applied the formula developed by Wischmeier and Smith (1978)as follows:

$$
R=\sum_{i=1}^{12} 1.735 \times 10^{\left(1.5 \times \log _{10}\left(P_{i}^{2} / P\right)-0.08188\right)}
$$

where $R$ is the rainfall erosivity factor $\left(\mathrm{MJ} \mathrm{mm} \mathrm{ha}{ }^{-1} \mathrm{~h}^{-1}\right.$ year $\left.{ }^{-1}\right) ; P_{i}$ is monthly rainfall $(\mathrm{mm})$; and $P$ is annual rainfall $(\mathrm{mm})$.

To obtain a spatially explicit determination raster layer of $R$ factor, we based our observation on the ANUSPLIN package which considers the elevation effect. ANUSPLIN package provides a facility for transparent analysis and interpolation of noisy multivariate data using thin plate smoothing splines (Hutchinson and $\mathrm{Xu}$ 2013). Precipitation data from ten rain-gauge stations located in the study area and 13 in the vicinity of the study area (Fig. 2) were collected to acquire an accurate $R$ factor layer.

\subsubsection{Soil erodibility factor $(K)$}

The soil erodibility factor $K$ is defined as the soil loss rate per rainfall erosion index unit for the specified soil under unit plot conditions, and it represents the effect of the inherent soil properties in soil erosion (Renard et al. 2011). The $K$ factor is related to soil texture, grain size, organic matter content, and other factors, which are derived from the soil type. In the erosion-productivity impact calculator (EPIC) (Rahman et al. 2009; Sharpley and Williams 1990), soil organic carbon and soil particle size were used to calculate the $K$ values. The formula was described as below:

$$
\begin{aligned}
K= & \left\{0.2+0.3 \exp \left[-0.0256 \mathrm{SAN}\left(1-\frac{\mathrm{SIL}}{100}\right)\right]\right\} \\
& \times\left(\frac{\mathrm{SIL}}{\mathrm{CLA}+\mathrm{SIL}}\right)^{0.3}\left(1.0-\frac{0.25 C}{C+\exp (3.72-2.95 C)}\right) \\
& \times\left(1.0-\frac{0.7 \mathrm{SN} 1}{\mathrm{SN} 1+\exp (-5.51+22.9 \mathrm{SN} 1)}\right)
\end{aligned}
$$

where SAN, SIL, and CLA are, respectively, the sand fraction (\%, 0.05-2.00-mm-diameter particles), silt fraction (\%, 0.002-0.05-mm-diameter particles), and clay fraction (\%, $<0.002-\mathrm{mm}$-diameter particles); $C$ is topsoil organic carbon content $(\%)$, and SN1 equals $1-\mathrm{SAN} / 100$.

In this study, the factor $K$ values were calculated using Eq. 3 and a soil map at 1:1,000,000 scale of The Second Soil Survey Data of China. 


\subsubsection{Topographic factor $(L S)$}

The slope length factor $(L)$ and slope steepness factor $(S)$ mainly reflect the effect of topography on erosion (Yildirim 2012). Slope length is defined as the horizontal distance from the point of origin of overland flow to the point where either the slope gradient decreases enough that deposition begins, or runoff is concentrated in a defined channel (Renard et al. 1997; Wischmeier and Smith 1978). Slope steepness reflects the influence of slope gradient on erosion. In general, an increase in the $L$ and/or $S$ factor produces higher overland flow velocities and correspondingly greater erosion (Ozsoy et al. 2012). Generating the $L$ and $S$ values poses the largest problem (Moore and Wilson 1992). Several scientists have developed some algorithms to calculate the slope length and steepness (Liu et al. 1994; McCool et al. 1987, 1989; Mitasova et al. 1996; Moore and Wilson 1992; Renard et al. 1991; Wischmeier and Smith 1978). The basic input to generate the $L$ and $S$ factor grid layers in GIS software was DEM dataset. Given that, the slope steepness of this area mainly ranges from $5^{\circ}$ to $40^{\circ}$ (accounting for $85.5 \%$ ), and the combination of the equations below can calculate the steepness accurately. The calculation of $L$ factor was calculated by the following formulas (McRoberts et al. 2002; Moore and Wilson 1992):

$$
\begin{gathered}
L=(\lambda / 22.13)^{m} \\
m=\beta /(1+\beta) \\
\beta=(\sin \theta / 0.0896) /\left[3.0(\sin \theta)^{0.8}+0.56\right]
\end{gathered}
$$

where $\lambda$ is the horizontal projection (m); $22.13=$ the RUSLE unit plot length (m); $m$ is a variable slope length exponent and $\theta$ is slope angle.

The $S$ factor was calculated based on the relationship (Liu et al. 1994; McCool et al. 1987) below:

$$
\begin{gathered}
S=10.8 \sin \theta+0.03 \quad \theta<5^{\circ} \\
S=16.8 \sin \theta-0.5 \quad 5^{\circ} \leq \theta<10^{\circ} \\
S=21.91 \sin \theta-0.96 \quad \theta \geq 10^{\circ}
\end{gathered}
$$

The $L$ and $S$ factors were calculated by Raster Calculator tool in ArcGIS. Then, the LS factor raster layer was further generated by multiplying $L$ factor and $S$ factor.

\subsubsection{Cover management factor $(C)$}

The cover management factor $(C)$ is a crucial factor to the erosion because it is a readily managed condition to reduce erosion (Renard et al. 2011). Soil loss is very sensible to land cover in addition to relief (Chatterjee et al. 2014). Soil erosion decreases exponentially with increase in vegetation cover. Plant cover reduces soil erosion by intercepting raindrops, enhancing infiltration, slowing down the movement of runoff (Gyssels et al. 2005; Wang et al. 2013). The individual values of $C$ factor vary from near zero for well-protected land cover to one for barren areas, reflecting abundance and type of the vegetation (Lee and Lee 2006). Higher values of $\mathrm{C}$ factor indicate no cover effect and high rate of soil loss, while lower values mean a very strong cover effect resulting in less erosion (Chatterjee et al. 2014). 
There are several methods to get the $C$ factor. Some studies determine $C$ factor value using land cover classification map assuming that the same land covers have the same $C$ factor values (Cebecauer and Hofierka 2008; Chatterjee et al. 2014; Lee 2004; Xu et al. 2011; Yang et al. 2012; Zhou et al. 2011), while some others use spectral mixture analysis (De Asis and Omasa 2007; Lu et al. 2004) or a regression analysis between C factor and spectral indices (e.g., NDVI, PVI) (Ma et al. 2003; Perovic et al. 2013; Tweddale et al. 2000; Xu et al. 2013; Zivotic et al. 2012). The regression analysis method was tested using NDVI data, but the result was not agreed well with other studies (Cai et al. 2000; Liu et al. 2009; Peng et al. 2007). To be specific, the values were overestimated, especially for forests. Taking into consideration the accuracy, in our study, $\mathrm{C}$ factor values were determined from land use classification according to relevant reports and local conditions.

The $\mathrm{C}$ value for forest land was 0.006 , mixed forest 0.05 , shrubland 0.02 , woody savannas and forest 0.03 , cropland 0.3 , cropland/natural vegetation mosaics 0.1 , water body and built-up 0, barren land 1 (Cai et al. 2000; Jiang et al. 2012; Liu et al. 2009; Peng et al. 2007).

\subsubsection{Conservation support practice factor $(P)$}

The $\mathrm{P}$ factor is defined as the ratio of soil loss with a specific support practice to the corresponding loss with upslope and downslope tillage (Renard et al. 1997). It is generally seen as reflecting the positive impact of management (Renard et al. 2011) that reduces the rate of water runoff. $P$ factor values range from zero to one, representing good man-made erosion resistance facility and lack of such facility, respectively. $P$ factor is usually estimated based on land use type. In this study, $P$ factor values referred to previous research results (Naqvi et al. 2013; Xu et al. 2009, 2013; Zhao et al. 2007). Cropland was assigned with 0.4 , barren land, water body and built-up with 0 , and other land cover types were 1 .

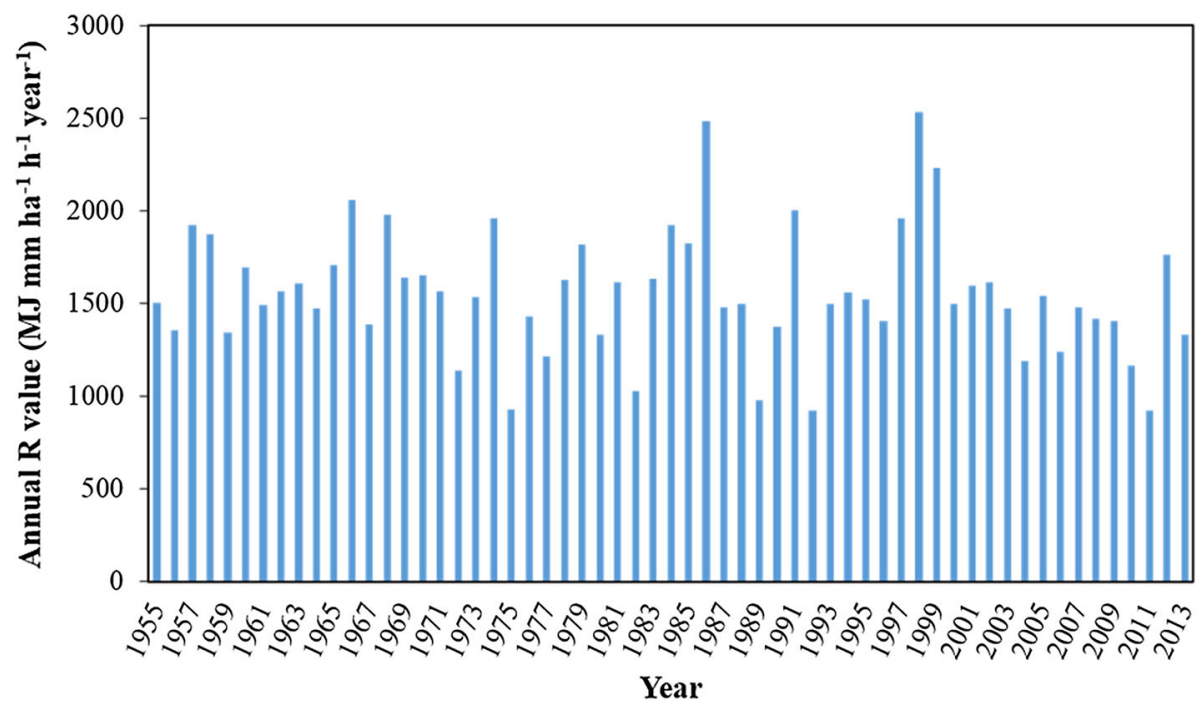

Fig. 3 Histogram of annual rainfall erosivity factor 


\subsection{Calculation of soil erosion}

To estimate the soil loss, all model factors of the RUSLE were represented by raster layers. After preparation of $R, K, \mathrm{LS}, C$, and $P$ factor data layers, they were multiplied using ArcGIS to obtain erosion map. Average soil loss was calculated by multiplying each pixel value of the erosion map layer and pixel area then divided by total pixel area of the study area. The classifications of soil erosion under different slopes and elevations were operated with the raster calculation function of ArcGIS.

\section{Results}

\subsection{RUSLE factors}

Statistically, the annual rainfall erosivity factor data series show that the value of annual $\mathrm{R}$ factor for the years 1955-2013 ranges from 923.5 to $2,534.9 \mathrm{MJ} \mathrm{mm} \mathrm{ha}^{-1} \mathrm{~h}^{-1}$ year $^{-1}$ (Fig. 3). The mean value of annual $R$ factor is observed to be 1,558.4 $\mathrm{MJ} \mathrm{mm} \mathrm{ha}{ }^{-1} \mathrm{~h}^{-1}$ year $^{-1}$, and the standard deviation is 200.8 which implies that the rainfall in the study area was unstable and obviously fluctuated. The figure of $R$ factor exhibits obvious spatial difference (Fig. 4). High values gather at the left bank of the main stream, while the low values are mainly clustered at the northeast part of the region. $R$ values of any place in the study area for RUSLE can be obtained from $R$ factor map in Fig. 4.
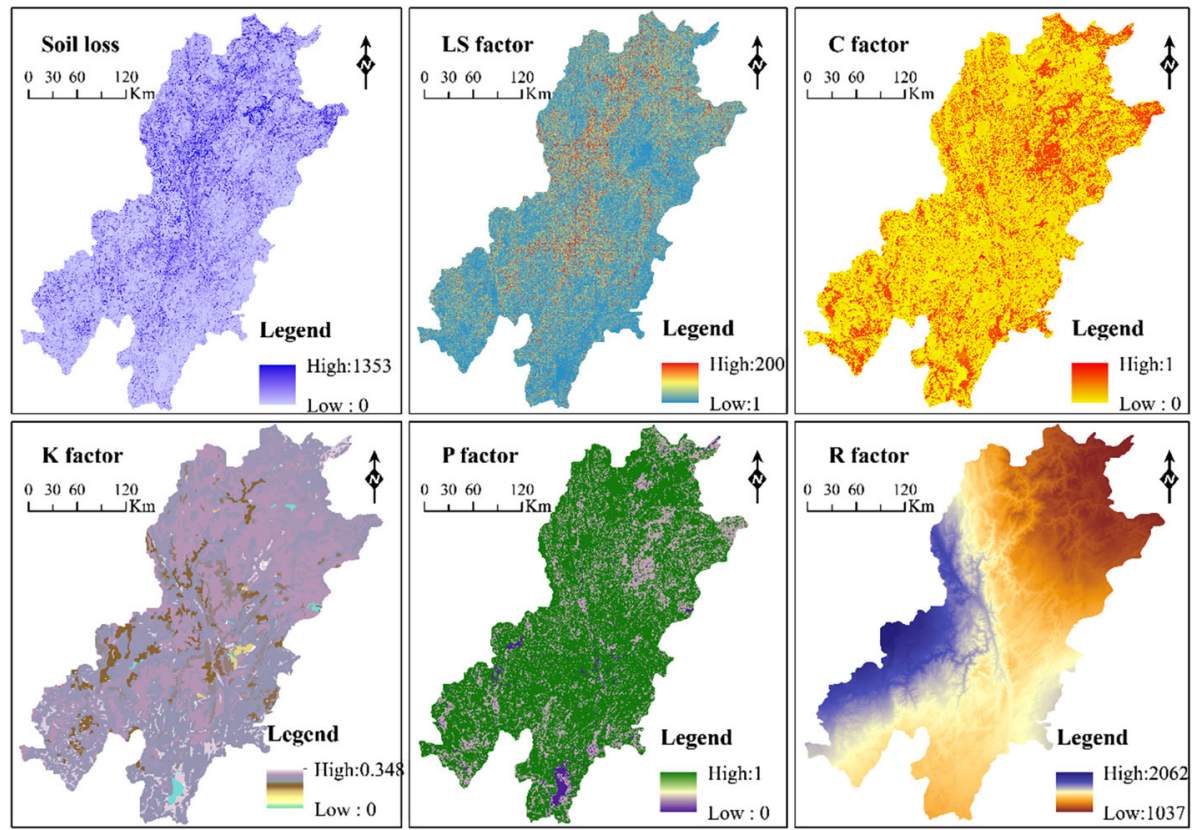

Fig. 4 Soil erosion modulus and factors of RUSLE model (Soil loss in $\mathrm{t} \mathrm{ha}^{-1}$ year ${ }^{-1} ; R$ factor in MJ mm ha ${ }^{-1} \mathrm{~h}^{-1}$ year $^{-1} ; K$ factor in $\mathrm{t} \mathrm{ha} \mathrm{h} \mathrm{ha}{ }^{-1} \mathrm{MJ}^{-1} \mathrm{~mm}^{-1}$; LS, $C$ and $P$ factors, dimensionless) 
LS values are directly related to surface relief. The high values were along the river courses and in the mountainous areas (Fig. 4). The average value for this area was 30.6 with a large standard deviation of 42.6 which indicates the LS values were relatively unevenly distributed.

The high values of $\mathrm{C}$ factor were scattered on the low vegetation-covered area, such as lake, reservoir, river, cultivated land, and build-up. The average value was 0.1 with a standard deviation of 0.13 . Owing large area of forest and grassland, the average value was lower.

$\mathrm{K}$ factor values were relatively discrete and unsteady due to the coarse resolution of available soil data. The values mainly ranged from 0.195 to $0.329 \mathrm{t}$ ha h ha ${ }^{-1} \mathrm{MJ}^{-1} \mathrm{~mm}^{-1}$, and the mean value was $0.265 \mathrm{t}$ ha h ha ${ }^{-1} \mathrm{MJ}^{-1} \mathrm{~mm}^{-1}$. The map of $\mathrm{K}$ values showed some clusters of lower value along river valleys (Fig. 4).

The $\mathrm{P}$ factor values were generally higher owing to the large area of forestland and grassland which lacked effective conservation practices.

\subsection{Estimate of soil loss}

The obtained results present the annual soil loss on a pixel by pixel basis (Fig. 4). Annual average soil erosion rate for the study area was estimated at $52.1 \mathrm{t} \mathrm{ha}^{-1}$ year $^{-1}$, and annual soil loss was $4.5 \times 10^{8}$ t. The statistical result of annual soil erosion rate by category (Table 1) indicates that $14.7 \%$ of the study area was under a slight erosion category, $35.3 \%$ under a light soil erosion category, and $19.5 \%$ under a moderate category of soil erosion. The severe to extreme erosion categories accounted for $30.5 \%$ of the total area although the percentage of extreme erosion category was only $8.1 \%$. Regarding annual soil loss on a mass basis, $62.3 \%$ of the total soil loss was derived from very severe and extreme erosion categories although their erosion areas only took up a small proportion less than $20 \%$ of total area. And the rest was mainly from moderate and severe erosion categories with equally percentage. $9.8 \%$ of soil loss was from light and slight erosion categories which were very low in comparison with their erosion area which accounted for $50 \%$ of total area. On the whole, the study area belonged to severe erosion category considering the average erosion rate of $52.1 \mathrm{t} \mathrm{ha}^{-1}$ year $^{-1}$.

Table 1 Statistics of soil erosion categories

\begin{tabular}{lllllcr}
\hline Category & $\begin{array}{l}\text { Criterion of } \\
\text { erosion modulus }{ }^{*}, \#\end{array}$ & $\begin{array}{l}\text { Area } \\
\text { percent } \\
(\%)\end{array}$ & $\begin{array}{l}\text { Erosion area } \\
\left(10^{4} \mathrm{ha}\right)\end{array}$ & $\begin{array}{l}\text { Avg. of } \\
\text { erosion rate }\end{array}$ & $\begin{array}{l}\text { Soil loss } \\
\text { percent }(\%)\end{array}$ & $\begin{array}{l}\text { Soil loss } \\
\left(10^{4} \mathrm{t}_{\mathrm{ear}}^{-1}\right)\end{array}$ \\
\hline Slight & $<5$ & 14.7 & 127.2 & 2.3 & 0.6 & 285.8 \\
Light & $5-25$ & 35.3 & 306.3 & 13.5 & 9.2 & $4,110.6$ \\
Moderate & $25-50$ & 19.5 & 169.5 & 36.0 & 13.5 & $6,048.3$ \\
Severe & $50-80$ & 11.9 & 103.4 & 63.3 & 14.5 & $6,492.0$ \\
Very & $80-150$ & 10.4 & 90.5 & 107.7 & 21.6 & $9,671.2$ \\
$\quad$ severe & & & & & & $18,226.9$ \\
Extreme & $>150$ & 8.1 & 70.4 & 260.8 & 40.7 & \\
\hline
\end{tabular}

* SL190-2007 (Ministry of Water Resource of China, 2007)

\# Unit: $\mathrm{t} \mathrm{ha}^{-1}$ year $^{-1}$ 


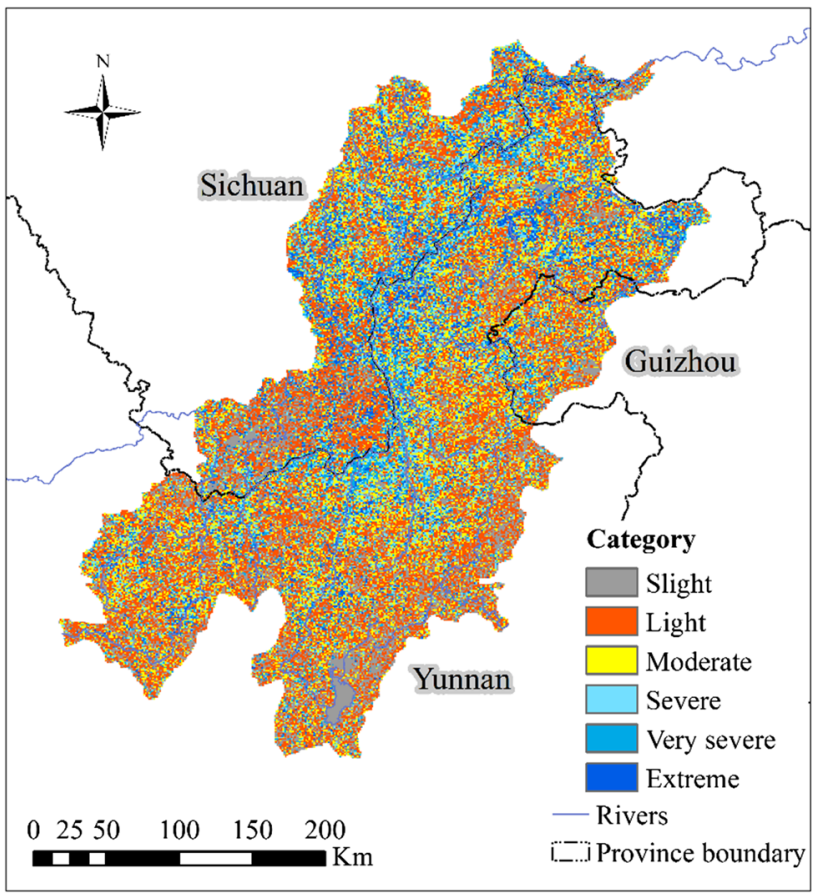

Fig. 5 Distribution of soil erosion intensity

As shown in Fig. 5, mountainous areas in the northwest and central part and river valleys had the severest soil erosion rate due to steep slopes, poor vegetation cover, and relatively heavy rain and runoff. The areas of low soil erosion rate were scattered in lake and lowland having a good ground cover, gentle slopes, and effective protection.

\section{Discussions}

\subsection{Soil erosion on different elevations and slopes}

The soil erosion category associated with different elevation zones is elaborated in Table 2. Around $96 \%$ of the erosion area was in the elevation zone of 838-3,350 m. To be more specific, nearly $62 \%$ of the erosion area occurred in the zone of 1,675-2,513 $\mathrm{m}$ and this zone was dominant no matter for any category. Therefore, it is essential to take conservation practices in the zone between 1,675 and $2,153 \mathrm{~m}$ to reduce soil loss. Meanwhile, the erosion in zone of $838-1,675 \mathrm{~m}$ cannot be ignored because severe to extreme categories in this zone took up a greater proportion.

While considering soil erosion on different slope zones (Table 3), around $95 \%$ of erosion occurred in the zone with slopes less than $35^{\circ}$ and excepting the less than $3^{\circ}$ slopes the severe erosion category was overpowered by light, moderate, and slight categories of erosion. In particular, higher values are found in the zone with slopes between $8^{\circ}$ and $25^{\circ}$, accounting for nearly $59 \%$ of total erosion area. The very severe and extreme soil erosion 
Table 2 Soil erosion category on elevation zones (percentage of area, \%)

\begin{tabular}{lrrrcccr}
\hline Elevation zone $(\mathrm{m})$ & Slight & Light & Moderate & Severe & Very severe & Extreme & Total \\
\hline$<838$ & 0.43 & 0.64 & 0.62 & 0.54 & 0.52 & 0.64 & 3.39 \\
$838-1,675$ & 1.67 & 5.12 & 3.68 & 2.80 & 2.81 & 2.88 & 18.96 \\
$1,675-2,513$ & 11.08 & 23.73 & 11.76 & 6.42 & 5.45 & 3.42 & 61.87 \\
$2,513-3,350$ & 1.36 & 5.52 & 3.25 & 2.00 & 1.56 & 1.17 & 14.85 \\
$>3,350$ & 0.13 & 0.31 & 0.23 & 0.16 & 0.08 & 0.02 & 0.93 \\
Total & 14.66 & 35.32 & 19.54 & 11.92 & 10.43 & 8.12 & 100.00 \\
\hline
\end{tabular}

Table 3 Soil erosion category on different slope zones (percentage of area, \%)

\begin{tabular}{lrrccccr}
\hline Slope & Slight & Light & Moderate & Severe & Very severe & Extreme & Total \\
\hline$<3^{\circ}$ & 2.00 & 1.92 & 0.73 & 0.38 & 0.29 & 0.19 & 5.52 \\
$3^{\circ}-8^{\circ}$ & 3.16 & 5.95 & 2.73 & 1.38 & 1.17 & 0.73 & 15.13 \\
$8^{\circ}-15^{\circ}$ & 4.62 & 11.11 & 5.46 & 2.84 & 2.46 & 1.83 & 28.32 \\
$15^{\circ}-25^{\circ}$ & 3.44 & 10.52 & 6.49 & 3.85 & 3.24 & 2.84 & 30.38 \\
$25^{\circ}-35^{\circ}$ & 1.14 & 4.36 & 3.03 & 2.37 & 2.13 & 1.79 & 14.83 \\
$>35^{\circ}$ & 0.30 & 1.42 & 1.11 & 1.10 & 1.15 & 0.75 & 5.83 \\
Total & 14.67 & 35.29 & 19.55 & 11.92 & 10.45 & 8.13 & 100.00 \\
\hline
\end{tabular}

categories are seen in the zone with slopes between $8^{\circ}$ and $25^{\circ}$, and the slight erosion category are mostly in the zone with slopes less than $15^{\circ}$.

\subsection{Comparison of soil erosion in sub-basins}

The spatial distribution characteristics of erosion are elaborated on a sub-basin level. The study area consists of 31 sub-basins which were generated from DEM using ArcSWAT. Average elevation, slope, and soil erosion rate of each sub-basin are presented on bar diagram in Fig. 6.

The top ten highest sub-basins with erosion rate more than $70 \mathrm{t} \mathrm{ha}^{-1}$ year $^{-1}$ were mainly situated along the main course of Jinsha River where the slopes were steep, including sub-basin 17, 6, 20, 15, 18, 13, 30, 19, 25, and 5 (Fig. 6). Sub-basins situated along the left side of Jinsha River had higher erosion rate than those along the right side. For example, the erosion rates of basin 10, 12, 17, 22, 26, 27 were more than $59 \mathrm{t} \mathrm{ha}^{-1}$ year $^{-1}$ which were higher than that of basin 1, 0, 3, 8, 16, 24, 28 with rates less than $55 \mathrm{t} \mathrm{ha}^{-1}$ year $^{-1}$ (Fig. 6).

The correlation analysis of erosion rate with slope and elevation of these sub-basins revealed that the correlationship between erosion and slope was very significant $(r=0.86$, $P<0.001)$ while that between erosion and elevation was not significant $(r=0.11$, $P=0.541)$. Therefore, it is essential to take conservation practices to reduce soil loss in steep slope areas, and specifically, as discussed above, areas with slopes between $15^{\circ}$ and $35^{\circ}$ should get key protection. 
Fig. 6 Spatial distribution of annual soil loss in sub-basins

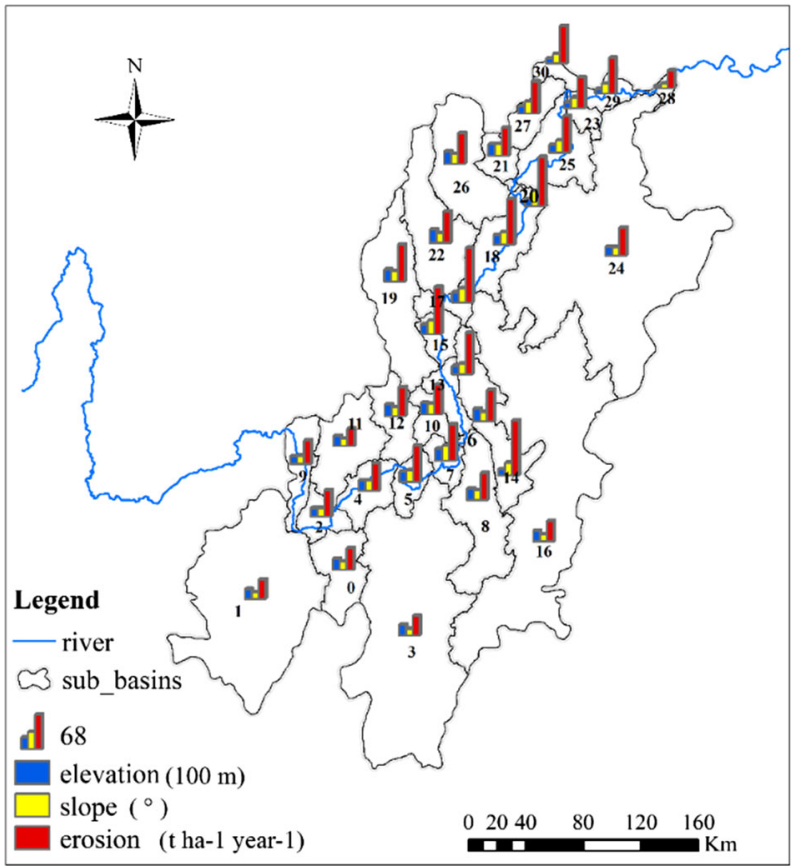

Table 4 Soil loss on different land use types

\begin{tabular}{lcccc}
\hline Land use type & $\begin{array}{l}\text { Area } \\
\text { percent }(\%)\end{array}$ & $\begin{array}{l}\text { Soil loss } \\
\left(10^{4} \mathrm{t} \mathrm{year}^{-1}\right)\end{array}$ & $\begin{array}{l}\text { Soil loss } \\
\text { percent }(\%)\end{array}$ & $\begin{array}{l}\text { Avg. erosion rate } \\
\left(\mathrm{t} \mathrm{ha}^{-1} \text { year }^{-1}\right)\end{array}$ \\
\hline Forest & 17.8 & $1,217.0$ & 2.7 & 7.4 \\
Mixed forest & 3.0 & $1,687.6$ & 3.8 & 66.9 \\
Shrubland & 17.6 & $4,019.8$ & 9.0 & 25.5 \\
Woody savannas & 0.4 & 127.9 & 0.3 & 33.9 \\
Grassland & 35.6 & $11,383.6$ & 25.4 & 38.0 \\
Cropland & 25.4 & $26,321.3$ & 58.7 & 122.7 \\
$\quad$ Cropland/Natural & 0.2 & 77.1 & 0.2 & 39.3 \\
$\quad$ vegetation mosaics & & & & \\
\hline
\end{tabular}

\subsection{Soil erosion on land use types}

The soil loss and erosion category on different land use types were also assessed (Tables 4, 5). The analysis shows that the croplands contributed $58.7 \%$ of total soil loss owing to its large erosion rate. The mean erosion rate of cropland was $122.7 \mathrm{t} \mathrm{ha}^{-1}$ year $^{-1}$ and twothirds of the cropland areas were under severe to extreme erosion categories. Therefore, soil conservation measures were urgently needed to control soil erosion of slope cultivated land, thereby reducing this massive soil loss. Grassland was the type of land cover that dominated the study area overwhelmingly (accounting for $35.6 \%$ ), from which the quantity of soil erosion made up a quarter of the total soil loss. Shrubland was the third 
Table 5 Soil erosion category on land use types (percentage of area, \%)

\begin{tabular}{lcrlllllr}
\hline Land use type & Slight & Light & Moderate & Severe & $\begin{array}{l}\text { Very } \\
\text { severe }\end{array}$ & Extreme & Total \\
\hline Forest & 6.9 & 10.4 & 0.4 & 0.0 & 0.0 & 0.0 & 17.8 \\
Mixed forest & 0.1 & 0.6 & 0.7 & 0.6 & 0.7 & 0.2 & 3.0 \\
Shrubland & 1.8 & 8.2 & 5.1 & 2.0 & 0.5 & 0.0 & 17.6 \\
Woody savannas & 0.0 & 0.2 & 0.1 & 0.1 & 0.0 & 0.0 & 0.4 \\
Grassland & 3.1 & 12.8 & 9.8 & 5.9 & 3.7 & 0.3 & 35.6 \\
$\begin{array}{l}\text { Cropland } \\
\text { Cropland/natural vegetation } \\
\text { mosaics }\end{array}$ & 0.9 & 3.8 & 3.7 & 3.5 & 5.6 & 7.8 & 25.4 \\
\hline & 0.0 & 0.1 & 0.1 & 0.0 & 0.0 & 0.0 & 0.2 \\
\hline
\end{tabular}

largest contributor due to its large area although the erosion rate of $25.5 \mathrm{t} \mathrm{ha}^{-1}$ year ${ }^{-1}$ was not very high. Comparatively, the mixed forest land had a high erosion rate of $66.9 \mathrm{t} \mathrm{ha}^{-1}$ year $^{-1}$ and $76.7 \%$ of this type had light to very severe erosion rate. Fortunately, this type has only $3 \%$ of total area and the soil loss accounted for merely $3.8 \%$. Woody savannas and cropland/natural vegetation mosaics had moderate erosion rate and took up smaller proportion in either erosion area or amount of soil loss.

As regards to soil erosion on different land use types, most of the soil erosion occurred in cropland and grassland, accounting for about $84 \%$ of the total soil loss, and the remained $16 \%$ occurred in other land use types (Table 4). It should be noted that nearly all of severe to extreme erosion categories were from grassland and cropland (Table 5). The key work of conservation practices should put emphasis on these two land use types taking into consideration their large areas and mass soil loss. And it indicates that forests play an important role in soil conservation. Therefore, the Natural Forest Conservation Program and Grain-to-Green Program in this region is essential and should be implemented strictly.

\subsection{Validation of the soil erosion estimation}

In China, the upper reach of Yangtze River, namely Jinsha River, is known for soil erosion due to deforestation and slope farmland reclamation. As the study revealed, the annual average annual total soil loss was $4.5 \times 10^{8} \mathrm{t}$ and soil erosion rate was estimated at $52.1 \mathrm{t} \mathrm{ha}^{-1}$ year $^{-1}$. This is why government implemented the "Chang Zhi" Project, i.e., Major Control Engineering of Soil and Water Conservation in upper and middle Yangtze River. Apparently, our government has to take many effective measures to carry out the project according to the relatively high erosion.

As a whole, the result obtained in this work agrees well with the conclusions of other studies inside this region or in adjacent areas (Peng et al. 2007; Yang et al. 2004, 2005; Zhang et al. 2003). To be specific, the erosion rate in Yiliang County bordering Songming and Chenggong Counties which lie in our study area on the southeast side is $44.26 \mathrm{t} \mathrm{ha}^{-1}$ year $^{-1}$ (Yang et al. 2005) or even higher (85.43 $\mathrm{t} \mathrm{ha}^{-1}$ year $^{-1}$ ) (Zhang et al. 2003). The erosion rate in Binchuan County adjoining Dayao County which is located in our study area is $34.58 \mathrm{t} \mathrm{ha}^{-1}$ year $^{-1}$ (Yang et al. 2004). And the erosion rate in Mouding County lying in our study area is $62.71 \mathrm{t} \mathrm{ha}^{-1}$ year $^{-1}$ (Zhang et al. 2003). Besides, the erosion rate in Lijiang County which is next to our study area is $52.50 \mathrm{t} \mathrm{ha}^{-1}$ year $^{-1}$ 
(Peng et al. 2007). These results indicate that our study result is reasonable and reliable. The methods and results described in this study are valuable for understanding the soil erosion in Jinsha River basin. And it is feasible to apply the RS, GIS, and the RUSLE model to assess soil erosion at a larger scale.

\section{Conclusions}

Soil erosion in Jinsha River basin is a serious problem, and assessment of soil erosion rate and soil loss is essential for water and soil conservation and sustainable development in this region. The application of RUSLE in GIS environment can be cost-saving and timesaving to estimate soil erosion over a large area. This study reveals that spatial annual average erosion rate was $52.1 \mathrm{t} \mathrm{ha}^{-1}$ year ${ }^{-1}$ classifying the area into severe soil erosion category. The annual soil loss was $4.5 \times 10^{8} \mathrm{t}$ and $62.3 \%$ of the total soil loss was derived from very severe and extreme erosion categories. Soil erosion is serious in the elevation zone between 1,675 and $2,153 \mathrm{~m}$ and slope zone with slopes between $15^{\circ}$ and $35^{\circ}$. Correlation analysis indicated that slope was a very crucial factor affecting soil erosion. Soil erosion had been assessed also in sub-basins. The results show that the sub-basins of erosion rate more than $70 \mathrm{tha}^{-1}$ year $^{-1}$ were mainly situated along the main course of Jinsha River. And spatially, sub-basins situated along the left side of Jinsha River had higher erosion rate than those along the right side. In terms of land use, grassland and cropland contributed mass majority to total soil loss. Thus, these areas need immediate attention from soil conservation point of view.

The RUSLE model and GIS techniques are very effective to estimate soil loss and erosion rate in this large area. The methods and results described in this study are valuable for understanding the situation of and relationship between soil erosion and environmental factors, which are useful to formulate and implement conservation program that will reduce soil erosion.

Acknowledgments This research was supported by National Key Technology Support Program of China (No. 2012BAC06B02) and Strategic Priority Research Program (B) of the Chinese Academy of Sciences (No. XDB03030400). We thank the Cold and Arid Regions Science Data Center at Lanzhou, Geospatial Data Cloud of Computer Network Information Center of Chinese Academy of Sciences, China Meteorological Data Sharing Service System and the Vlaamse Instelling Voor Technologish Onderzoek for providing some datasets. All assistance received has been greatly appreciated.

\section{References}

Briggs D, Giordano A, Cornaert M, Peter D, Maes J (1992) CORINE soil erosion risk and important land resources in the southern regions of the European Community. Commission of the European Communities Publication EUR 13233

Cai CF, Ding SW, Shi ZH, Huang L, Zhang GY (2000) Study of applying USLE and geographical information system IDRISI to predict soil erosion in small watershed. J Soil Water Conserv 14:19-24 (in Chinese)

Cebecauer T, Hofierka J (2008) The consequences of land-cover changes on soil erosion distribution in Slovakia. Geomorphology 98:187-198

Chatterjee S, Krishna AP, Sharma AP (2014) Geospatial assessment of soil erosion vulnerability at watershed level in some sections of the Upper Subarnarekha river basin, Jharkhand, India. Environ Earth Sci 71:357-374

da Silva AM (2004) Rainfall erosivity map for Brazil. Catena 57:251-259 
De Asis AM, Omasa K (2007) Estimation of vegetation parameter for modeling soil erosion using linear Spectral Mixture Analysis of Landsat ETM data. Int J Photogramm Remote Sens 62:309-324

Diodato N (1999) Estimating RUSLE's rainfall factor in the part of Italy with a Mediterranean rainfall regime. Hydrol Earth Syst Sci 8:103-107

Fan JR, Zhang JH, Zhong XH, Liu SZ, Tao HP (2004) Monitoring of soil erosion and assessment for contribution of sediments to rivers in a typical watershed of the Upper Yangtze River Basin. Land Degrad Dev 15:411-421

Gyssels G, Poesen J, Bochet E, Li Y (2005) Impact of plant roots on the resistance of soils to erosion by water: a review. Prog Phys Geog 29:189-217

Hutchinson MF, Xu T (2013) ANUSPLIN Version 4.4 User Guide

Jiang ZL, Su SL, Jing CW, Lin SP, Fei XF, Wu JP (2012) Spatiotemporal dynamics of soil erosion risk for Anji County, China. Stoch Environ Res Risk Assess 26(6):751-763

Kavian A, Fathollah Nejad Y, Habibnejad M, Soleimani K (2011) Modeling seasonal rainfall erosivity on a regional scale: a case study from Northeastern Iran. Int J Environ Res 5:939-950

Lee S (2004) Soil erosion assessment and its verification using the Universal Soil Loss Equation and Geographic Information System: a case study at Boun, Korea. Environ Geol 45:457-465

Lee G-S, Lee K-H (2006) Scaling effect for estimating soil loss in the RUSLE model using remotely sensed geospatial data in Korea. Hydrol Earth Syst Sc Discuss 3:135-157

Liu B, Nearing M, Risse L (1994) Slope gradient effects on soil loss for steep slopes. Trans ASAE $37: 1835-1840$

Liu AX, Wang J, Liu ZJ (2009) Remote sensing quantitative monitoring of soil erosion in Three Gorges Reservoir area: a GIS/RUSLE based research. J Nat Disaster 18(4):25-30 (in Chinese)

Long HL, Heilig GK, Wang J, Li XB, Luo M, Wu XQ, Zhang M (2006) Land use and soil erosion in the upper reaches of the Yangtze River: some socio-economic considerations on China's Grain-for-Green Programme. Land Degrad Dev 17:589-603

Lu D, Li G, Valladares GS, Batistella M (2004) Mapping soil erosion risk in Rondonia, Brazilian Amazonia: Using RULSE, remote sensing and GIS. Land Degrad Dev 15:499-512

Ma JW, Xue Y, Ma CF, Wang ZG (2003) A data fusion approach for soil erosion monitoring in the Upper Yangtze River Basin of China based on Universal Soil Loss Equation (USLE) model. Int J Remote Sens 24:4777-4789

McCool D, Brown L, Foster G, Mutchler C, Meyer L (1987) Revised slope steepness factor for the Universal Soil Loss Equation. Trans ASAE 30(5):1387-1396

McCool D, Foster G, Mutchler C, Meyer L (1989) Revised slope length factor for the Universal Soil Loss Equation. Trans ASAE 32(5):1571-1576

McRoberts RE, Nelson MD, Wendt DG (2002) Stratified estimation of forest area using satellite imagery, inventory data, and the k-Nearest Neighbors technique. Remote Sens Environ 82:457-468

Merritt WS, Letcher RA, Jakeman AJ (2003) A review of erosion and sediment transport models. Environ Model Softw 18:761-799

Mitasova H, Hofierka J, Zlocha M, Iverson LR (1996) Modelling topographic potential for erosion and deposition using GIS. Int J Geogr Inf Syst 10:629-641

Moore ID, Wilson JP (1992) Length-slope factors for the Revised Universal Soil Loss Equation: Simplified method of estimation. J Soil Water Conserv 47:423-428

Naqvi HR, Mallick J, Devi LM, Siddiqui MA (2013) Multi-temporal annual soil loss risk mapping employing Revised Universal Soil Loss Equation (RUSLE) model in Nun Nadi Watershed, Uttrakhand (India). Arab Geosci 6:4045-4056

Onori F, Bonis P, Grauso S (2006) Soil erosion prediction at the basin scale using the revised universal soil loss equation (RUSLE) in a catchment of Sicily (southern Italy). Environ Geol 50:1129-1140

Onyando JO, Kisoyan P, Chemelil MC (2005) Estimation of potential soil erosion for River Perkerra catchment in Kenya. Water Resour Manag 19:133-143

Ozsoy G, Aksoy E, Dirim MS, Tumsavas Z (2012) Determination of soil erosion risk in the Mustafakemalpasa River Basin, Turkey, using the Revised Universal Soil Loss Equation, Geographic Information System, and Remote Sensing. Environ Manag 50:679-694

Pan JH, Wen Y (2014) Estimation of soil erosion using RUSLE in Caijiamiao watershed, China. Nat Hazards 71:2187-2205

Peng J, Li DD, Zhang YQ (2007) Analysis of spatial characteristics of soil erosion in mountain areas of Northwestern Yunnan based on GIS and RUSLE. J Mt Sci 25(5):548-556 (in Chinese)

Perovic V, Zivotic L, Kadovic R, Dordevic A, Jaramaz D, Mrvic V, Todorovic M (2013) Spatial modelling of soil erosion potential in a mountainous watershed of South-eastern Serbia. Environ Earth Sci $68: 115-128$ 
Rahman MR, Shi Z, Chongfa C (2009) Soil erosion hazard evaluation-an integrated use of remote sensing, GIS and statistical approaches with biophysical parameters towards management strategies. Ecol Model 220:1724-1734

Renard KG, Foster GR, Weesies GA, Porter JP (1991) RUSLE: revised universal soil loss equation. J Soil Water Conserv 46:30-33

Renard KG, Foster GR, Weesies GA, McCool D, Yoder D (1997) Predicting soil erosion by water: a guide to conservation planning with the revised universal soil loss equation (RUSLE). Agriculture Handbook (Washington)

Renard K, Yoder D, Lightle D, Dabney S (2011) Universal soil loss equation and revised universal soil loss equation. Handbook of erosion modelling. Blackwell Publ, Oxford, pp 137-167

Saadat H, Adamowski J, Tayefi V, Namdar M, Sharifi F, Ale-Ebrahim S (2014) A new approach for regional scale interrill and rill erosion intensity mapping using brightness index assessments from medium resolution satellite images. Catena 113:306-313

Shamshad A, Azhari M, Isa M, Hussin W, Parida B (2008) Development of an appropriate procedure for estimation of RUSLE $\mathrm{EI}_{30}$ index and preparation of erosivity maps for Pulau Penang in Peninsular Malaysia. Catena 72:423-432

Sharpley AN, Williams JR (1990) EPIC-erosion/productivity impact calculator: 1. Model documentation. Technical Bulletin-United States Department of Agriculture

Shen Z, Chen L, Ding X, Hong Q, Liu R (2013) Long-term variation (1960-2003) and causal factors of nonpoint-source nitrogen and phosphorus in the upper reach of the Yangtze River. J Hazard Mater 252:45-56

Tweddale SA, Echlschlaeger CR, Seybold WF (2000) An improved method for spatial extrapolation of vegetative cover estimates (USLE/RUSLE C factor) using LCTA and remotely sensed imagery. US Army Corps of Engineers, Engineer Research and Development Center, Construction Engineering Research Laboratory, ERDC Technical Report

Van der Knijff J, Jones R, Montanarella L (2000) Soil erosion risk assessment in Europe. European Soil Bureau, European Commission

Wang LH, Huang JL, Du Y, Hu YX, Han PP (2013) Dynamic assessment of soil erosion risk using Landsat TM and HJ satellite data in Danjiangkou Reservoir area, China. Remote Sens 5:3826-3848

Wischmeier WH, Smith DD (1978) Predicting rainfall erosion losses: a guide to conservation planning. U.S Department of Agriculture, Washington, DC

Xu YQ, Peng J, Shao XM (2009) Assessment of soil erosion using RUSLE and GIS: a case study of the Maotiao River watershed, Guizhou Province, China. Environ Geol 56:1643-1652

Xu YQ, Luo D, Peng J (2011) Land use change and soil erosion in the Maotiao River watershed of Guizhou Province. J Geog Sci 21:1138-1152

Xu L, Xu X, Meng X (2013) Risk assessment of soil erosion in different rainfall scenarios by RUSLE model coupled with Information Diffusion Model: a case study of Bohai Rim, China. Catena 100:74-82

Yang X (2014) Deriving RUSLE cover factor from time-series fractional vegetation cover for hillslope erosion modelling in New South Wales. Soil Res 52:253

Yang ZS, He YM, Li YH, Zhang YL, Wang YP (2004) Land use change and soil erosion control in Dry-hot Valley Zone in the middle reaches of Jinsha River during 1960-2000: a case study in Binchuan County, Yunnan Province. Prog Geog 23(2):16-26 (in Chinese)

Yang ZS, Liu YS, Liang LH, He YM, Zhang YL, Wang YP (2005) A change of soil erosion from 1960 to 2000 in the lower reaches of Jinsha River: A case study in Yiliang County, Yunnan Province. J Moun Sci 23(2):144-152 (in Chinese)

Yang M, Li X, Hu Y, He X (2012) Assessing effects of landscape pattern on sediment yield using sediment delivery distributed model and a landscape indicator. Ecol Indic 22:38-52

Yildirim U (2012) Assessment of soil erosion at the Deðirmen Creek watershed area. Afyonkarahisar, Turkey, pp 73-80

Yu B, Rosewell C (1996a) Rainfall erosivity estimation using daily rainfall amounts for South Australia. Soil Res 34:721-733

Yu B, Rosewell C (1996b) A robust estimators of the R-reaction for the universal soil loss equation. Trans ASAE 39:559-561

Zhang XB, Zhang YY, Wen AB, Feng MY (2003) Assessment of soil losses on cultivated land by using the 137Cs technique in the Upper Yangtze River Basin of China. Soil Till Res 69(1):99-106

Zhao L, Yuan GL, Zhang Y, He B, Liu ZH, Wang ZY, Li J (2007) The amount ofsoil erosion in Baoxiang watershed of Dianchi Lake based on GIS and USLE. Bull Soil Water Conser 27(3):42-46 (in Chinese)

Zhou J, Zhang X, He D, Zhou J, Zhou X, Wang Z (2011) Soil erosion evaluation of small watershed in Wuling Mountain based on GIS and URSLE. Resour Environ Yangtze Basin 20(4):468-474 (in Chinese) 
Zhuang JQ, Ge YG (2012) Assessment of the soil loss associated to land use and precipitation change in the Xiaojiang River basin, Southwest China. Resour Environ Yangtze Basin 21(3):288-295 (in Chinese)

Zivotic L, Perovic V, Jaramaz D, Dordevic A, Petrovic R, Todorovic M (2012) Application of USLE, GIS, and Remote Sensing in the assessment of soil erosion rates in Southeastern Serbia. Pol J Environ Stud 21:1929-1935 